\title{
In Vitro Evaluation of the Antioxidant Activity and Wound Healing Properties of Jaboticaba (Plinia peruviana) Fruit Peel Hydroalcoholic Extract
}

\author{
Heloisa da S. Pitz, Aline Pereira, Mayara B. Blasius, \\ Ana Paula L. Voytena, Regina C. L. Affonso, Simone Fanan, Adriana C. D. Trevisan, \\ Rosa M. Ribeiro-do-Valle, and Marcelo Maraschin
}

Plant Morphogenesis and Biochemistry Laboratory, Federal University of Santa Catarina, 1346 Admar Gonzaga Road, 88048-000 Florianópolis, SC, Brazil

Correspondence should be addressed to Heloisa da S. Pitz; heloisapitz@gmail.com

Received 17 June 2016; Accepted 25 July 2016

Academic Editor: Pavel Pospisil

Copyright $\odot 2016$ Heloisa da S. Pitz et al. This is an open access article distributed under the Creative Commons Attribution License, which permits unrestricted use, distribution, and reproduction in any medium, provided the original work is properly cited.

Jaboticaba is a fruit from a native tree to Brazil, Plinia peruviana. Jaboticaba peels are an important source of antioxidant molecules such as phenolic compounds. This study aimed to evaluate in vitro the activity of a hydroalcoholic extract of jaboticaba fruit peels (HEJFP) in wound healing processes and antioxidant activity in murine fibroblasts (L929 cell line). HEJFP concentrations $(0.5,1,5$, $10,25,50,100$, and $200 \mu \mathrm{g} / \mathrm{mL}$ ) were tested in MTT assay and cell proliferation was verified at $100 \mu \mathrm{g} / \mathrm{mL}$ after $24 \mathrm{~h}$ and at 25,50 , and $100 \mu \mathrm{g} / \mathrm{mL}$ after $48 \mathrm{~h}$ of extract exposure. Evaluation of antioxidant activity was performed at $0.5,5,25,50$, and $100 \mu \mathrm{g} / \mathrm{mL} \mathrm{HEJFP}$ concentrations. Cell treatment with HEJFP at 25,50 , and $100 \mu \mathrm{g} / \mathrm{mL}$ for $24 \mathrm{~h}$ followed by $\mathrm{H}_{2} \mathrm{O}_{2}$ exposure for $3 \mathrm{~h}$ showed a strong cytoprotective effect. In vitro scratch wound healing assay indicated that none of tested HEJFP concentrations $(0.5,5,25,50$, and $100 \mu \mathrm{g} / \mathrm{mL}$ ) were capable of increasing migration rate after $12 \mathrm{~h}$ of incubation. These results demonstrate a positive effect of HEJFP on the wound healing process on L929 fibroblasts cell line, probably due to the antioxidant activity exhibited by phytochemicals in the extract.

\section{Introduction}

Wound healing is a process divided into three interactive and overlapping phases classified as inflammation, tissue formation, and tissue remodeling [1]. During inflammation, neutrophils and monocytes invade the injury tissue and start to secrete proteolytic enzymes, proinflammatory cytokines, and growth factors. Besides, these cells also secrete reactive oxygen species (ROS), important molecules that defend the body against bacteria and microorganism invasion [2].

The next phase known as tissue formation is characterized by proliferation and migration of fibroblasts and keratinocytes from the wound edge to the wound bed [3]. Angiogenesis is triggered and leads to the formation of granulation tissue, which is important to support the nutrients and oxygen supply in injured tissue [4-6]. In this tissue, fibroblasts become myofibroblasts which synthesize and deposit extracellular matrix (ECM) compounds, especially collagen. Besides, these cells are responsible for wound contraction and maturation of the granulation tissue [7].

At remodeling phase, there is a reduction on cellularity due to the apoptosis of myofibroblasts, endothelial cells, and inflammatory cells. The synthesis of ECM is reduced and ECM's components are modified as the matrix is remodeled [8].

Impaired wound healing is a problem that may be caused by uncontrolled inflammatory and immune responses, microbial infection, and excessive ROS production [9]. Excessive amounts of ROS may modify and/or degrade ECM proteins and damage dermal fibroblasts and keratinocytes functions. Besides, ROS-mediated transcription causes the maintained proinflammatory cytokines secretion and induction of matrix metalloproteases [10]. 
Jaboticaba is a fruit from a native tree to Brazil, that is, Plinia peruviana. Studies have shown important biological properties of anthocyanins, mainly those related to antiinflammatory activity and antioxidative stress [11]. Jaboticaba fruit peels are the main source of anthocyanins in the fruit and it has been used in traditional medicine to treat diarrhea, skin irritation, hemoptysis, and asthma [12-14]. This study aimed to evaluate the antioxidant activity of a HEJFP and its role in wound healing processes as migration and proliferation of murine fibroblasts (L929 cell line).

\section{Materials and Methods}

2.1. Plant Material Collection and Extraction. Fruits of $P$. peruviana were collected from a backyard format planting system during the harvest season (spring, 2014) in Guaxupé, Minas Gerais, Brazil. The plant was authenticated by Dr. Marcos Sobral and a voucher specimen (FLOR 55902) was preserved at FLOR herbarium (Department of Botany, Federal University of Santa Catarina, Florianópolis, southern Brazil).

The fruit peels of jaboticaba were lyophilized and powdered by an electric grinder. The dried and powdered biomass was added to $50 \%$ ethanol solution $(\mathrm{v} / \mathrm{v}), \mathrm{pH} 3.6(1: 10 \mathrm{w} / \mathrm{v})$. The mixture was microwaved (three pulses of five seconds with 60 seconds of interval between each of the pulses) to extract the compounds of interest. The HEJFP was recovered by filtration on cellulose membranes under vacuum.

2.2. Determination of Total Phenolic Content. The total phenolic content of HEJFP was measured spectrophotometrically [15]. For that, HEJFP was diluted in 50\% ethanol solution, $\mathrm{pH} 3.6(1: 10 \mathrm{v} / \mathrm{v})$. Subsequently, $1 \mathrm{~mL}$ of HEJFP previously diluted was added to $5 \mathrm{~mL} 95 \%$ methanol solution. After this second dilution, sample $(1 \mathrm{~mL})$ was added to $1 \mathrm{~mL}$ 95\% ethanol solution, $5 \mathrm{~mL}$ distilled water, and $0.5 \mathrm{~mL}$ FolinCiocalteu's reagent and incubated for $7 \mathrm{~min}$.

After incubation, $1 \mathrm{~mL}$ 5\% sodium carbonate solution was added and kept in the darkness at room temperature for $1 \mathrm{~h}$. A blank solution was prepared as described above replacing the sample by $50 \%$ of ethanol solution, $\mathrm{pH}$ 3.6. The absorbance was measured at $725 \mathrm{~nm}$, using a UV-Vis spectrophotometer (BEL LGS 53, BEL Engineering, Monza, Italy).

The total phenolic compounds were quantified using a standard curve of gallic acid. The results were expressed as $\mathrm{mg}$ gallic acid equivalents/g dry weight of jaboticaba biomass.

2.3. Determination of the Total Flavonoid Content. The determination of total flavonoids was based on aluminum chloride colorimetric method [16].

Previously, HEJFP was diluted in $50 \%$ ethanol solution, $\mathrm{pH} 3.6(1: 10 \mathrm{v} / \mathrm{v}) .0 .5 \mathrm{~mL}$ of diluted HEJFP was added to $2.5 \mathrm{~mL}$ ethanol and $0.5 \mathrm{~mL} 2 \%$ aluminum chloride diluted in methanol and incubated for $1 \mathrm{~h}$. A blank solution was prepared as described above replacing the sample by $50 \%$ of ethanol solution, $\mathrm{pH}$ 3.6. The absorbance was measured at $420 \mathrm{~nm}$ in a UV-Vis spectrophotometer (BEL LGS 53, BEL Engineering, Monza, Italy). The quantification of total flavonoids was carried out using a quercetin standard curve.
The results were expressed as mg quercetin equivalents/g dry weight of jaboticaba biomass.

2.4. Antioxidant Activity (DPPH Assay). The 2,2-diphenyl2-picrylhydrazyl (DPPH) assay is a chemical method that measures the capacity of a compound to scavenge free radicals based on the decrease in absorbance during the reaction [17]. A stock solution of $0,0079 \mathrm{~g}$ of $\mathrm{DPPH}$ was diluted in $2.5 \mathrm{~mL}$ methanol. This solution was further diluted in a concentration of $1: 100(\mathrm{v} / \mathrm{v})$ in $80 \%$ methanol (v/v). The absorbance of this DPPH solution should be around 0.5 and 0.6. The HEJFP, previously diluted in 50\% ethanol, $\mathrm{pH} 3.6$, at $1: 100(\mathrm{v} / \mathrm{v})$, was added to $\mathrm{DPPH} / 80 \%$ methanol solution $(1: 30 \mathrm{v} / \mathrm{v})$. The capacity of the HEJFP to inhibit DPPH radicals was measured spectrophotometrically at $515 \mathrm{~nm}$, after incubation for $5,10,20,30,40$, and $50 \mathrm{~min}$ in the dark, at room temperature. The same procedure described above was used to test the $50 \%$ ethanol, $\mathrm{pH} 3.6$, solution to ensure that the solvent was not reacting with DPPH/80\% methanol solution. The percentage of inhibition of DPPH radicals was calculated by the following formula (Abs. = absorbance):

inhibition DPPH (\%)

$$
\begin{aligned}
= & \frac{\text { Abs. DPPH } / 80 \% \text { methanol solution }- \text { Abs. HEJFP }}{\text { Abs. DPPH } / 80 \% \text { methanol solution }} \\
& \times 100 \text {. }
\end{aligned}
$$

2.5. Cell Proliferation and Viability Assay Using L929 Fibroblast. L929 mouse fibroblast cells were seeded at a density of $5 \times 10^{3}$ cells/well into a 96-well plate in DMEM culture medium supplemented with $10 \%$ FBS and incubated at $37^{\circ} \mathrm{C}$, in a humidified $5 \% \mathrm{CO}_{2}$ atmosphere overnight. After incubation, DMEM was replaced by DMEM 10\% FBS containing $0.5,1,5,10,25,50,100$, and $200 \mu \mathrm{g} / \mathrm{mL}$ (dry weight) of HEJFP, except in control, where the culture medium was replaced by fresh DMEM. Cells were incubated for $24 \mathrm{~h}$ and $48 \mathrm{~h}$, at $37^{\circ} \mathrm{C}$, in a humidified $5 \% \mathrm{CO}_{2}$ atmosphere. Afterwards, the culture medium was replaced by $100 \mu \mathrm{L}$ of fresh DMEM along with $10 \mu \mathrm{L}$ 3-(4,5-dimethylthiazol-2-yl)2,5-diphenyltetrazolium bromide (MTT) solution $(5 \mathrm{mg} / \mathrm{mL}$ in PBS) per well and incubated in the dark, for $3 \mathrm{~h}$, at $37^{\circ} \mathrm{C}$, in a humidified $5 \% \mathrm{CO}_{2}$ atmosphere. A negative control without cells with $100 \mu \mathrm{L}$ of DMEM and $10 \mu \mathrm{L}$ of MTT solution was required. Subsequently, $85 \mu \mathrm{L}$ of culture medium was removed and $50 \mu \mathrm{L}$ of DMSO was added onto each well and incubated for more $10 \mathrm{~min}$, at $37^{\circ} \mathrm{C}$, in a humidified $5 \% \mathrm{CO}_{2}$ atmosphere. After homogenizing formazan crystals, the absorbance at $540 \mathrm{~nm}$ was determined by an ELISA plate reader. The percentage of cell proliferation/viability was calculated and compared to control (100\% of viability).

2.6. Hydrogen Peroxide-Induced Oxidative Stress in L929 Fibroblast Cells and Evaluation of Cell Survival. Hydrogen peroxide was used for induction of oxidative stress as described by Balekar et al. [18] and Ponnusamy et al. [19]. The L929 fibroblast cells were seeded at a density of $5 \times 10^{3}$ cells/well into a 96-well plate in DMEM supplemented with $10 \% \mathrm{FBS}$ and incubated at $37^{\circ} \mathrm{C}$, in a humidified $5 \% \mathrm{CO}_{2}$ 
atmosphere overnight. A curve with $\mathrm{H}_{2} \mathrm{O}_{2}$ concentrations $(0.0625,0.125,0.25,0.5$, and $1.0 \mathrm{mM})$ was built to determine $\mathrm{H}_{2} \mathrm{O}_{2}$ dose which decreases cell viability by $80 \%$ after $24 \mathrm{~h}$ of exposure using MTT assay. The chosen concentration was $1.0 \mathrm{mM}$ of $\mathrm{H}_{2} \mathrm{O}_{2}$. Subsequently, L929 fibroblast cells were seeded at a density of $5 \times 10^{3}$ cells/well into a 96-well plate containing DMEM culture medium supplemented with $10 \%$ FBS and incubated overnight at $37^{\circ} \mathrm{C}$, in a humidified $5 \% \mathrm{CO}_{2}$ atmosphere. After incubation, DMEM with $10 \%$ FBS containing $0.5,5,25,50$, and $100 \mu \mathrm{g} / \mathrm{mL}$ (dry weight) of HEJFP was used to treat cells in different times as follows: (1) cells were treated for $24 \mathrm{~h}$ followed by $1.0 \mathrm{mM}$ of $\mathrm{H}_{2} \mathrm{O}_{2}$ exposure for $3 \mathrm{~h}$, (2) cells were exposed concomitantly to HEJFP and $1.0 \mathrm{mM}$ of $\mathrm{H}_{2} \mathrm{O}_{2}$ for $24 \mathrm{~h}$, and (3) cells were exposed to $1.0 \mathrm{mM}$ of $\mathrm{H}_{2} \mathrm{O}_{2}$ for $3 \mathrm{~h}$ followed by cells treatment with HEJFP for $24 \mathrm{~h}$. Evaluation of cell survival was performed using MTT assay as described above.

2.7. Scratch Assay. The stimulatory effect of HEJFP on migration of L929 cells was determined as described by Balekar et al. [18]. The L929 fibroblast cells were seeded at a density of $5 \times 10^{5}$ cells/well into a 24-well plate containing DMEM culture medium supplemented with $10 \%$ FBS and incubated overnight at $37^{\circ} \mathrm{C}$, in a humidified $5 \% \mathrm{CO}_{2}$ atmosphere. After incubation, DMEM was completely removed and the adherent cell layer was scratched with a sterile yellow pipette tip. Cellular debris was removed by washing off with phosphate buffer saline (PBS). The cells were treated with DMEM with $10 \%$ FBS containing $0.5,5,25,50$, and $100 \mu \mathrm{g} / \mathrm{mL}$ (dry weight) of HEJFP. Controls received only fresh DMEM. To avoid proliferation of cells, mitomycin $\mathrm{C}(10 \mu \mathrm{g} / \mathrm{mL})$ was added in each well along with control and HEJFP-treated cells; this way only migration was evaluated. The cells were incubated (at $37^{\circ} \mathrm{C}$ in humidified $5 \% \mathrm{CO}_{2}$ atmosphere for $12 \mathrm{~h}$ ) and then the recording of images of the scratch area was carried out in two different points, using a built-in camera in the microscope (40x magnification) at $0 \mathrm{~h}$ (just after scratching cells) and at $12 \mathrm{~h}$ after incubation with HEJFP and control. Data were analyzed with ImageJ $1.42 \mathrm{q}$ imaging software (National Institutes for Health, US) in order to determine the width of the scratch and thus to calculate the rate of migration of cells by the following formula:

$$
\text { migration rate }(\%)=\frac{\text { distance within scratch }(0 \mathrm{~h})-\text { distance within scratch }(12 \mathrm{~h})}{\text { distance within scratch }(0 \mathrm{~h})} \times 100 \text {. }
$$

2.8. Statistical Analysis. Data were collected and summarized, followed by statistical analysis using one-way ANOVA and Tukey's test. $P$ values lower than 0.05 were considered to be statistically significant. The values were expressed as mean $\pm \mathrm{SD}$ or median as indicated in figures' captions.

\section{Results}

3.1. Total Phenolic and Flavonoid Contents of the Hydroalcoholic Extract. The total phenol and flavonoid contents of HEJFP were 92,2 $\pm 9,75 \mathrm{mg}$ gallic acid equivalent/g and 6,43 $\pm 0,49 \mathrm{mg}$ quercetin equivalent/g, respectively.

3.2. Antioxidant Activity. DPPH radical scavenging of HEJFP was measured in different times to determine the peak of antioxidant capacity. After $5 \mathrm{~min}$ of incubation, HEJFP inhibited $83.6 \%$ of DPPH radicals, showing an excellent antioxidant activity in few minutes of reaction. At $30 \mathrm{~min}$ of incubation, 91\% scavenging activity was achieved and it remained until 50 minutes of reaction (Table 1).

3.3. Cell Proliferation and Viability. The effect of HEJFP on both cell proliferation and viability was evaluated in L929 murine fibroblasts cell line in different concentrations after $24 \mathrm{~h}$ and $48 \mathrm{~h}$, using MTT assay.

HEJFP was able to promote cell proliferation at $100 \mu \mathrm{g} / \mathrm{mL}$ after $24 \mathrm{~h}$ and at 25,50 , and $100 \mu \mathrm{g} / \mathrm{mL}$ after $48 \mathrm{~h}$. The concentration of $200 \mu \mathrm{g} / \mathrm{mL}$ was shown to be cytotoxic in both times of exposure, decreasing significantly cell viability. For the other concentrations assayed, the cell viability was higher than $80 \%$ (Figure 1).
3.4. Hydrogen Peroxide-Induced Oxidative Stress and Cell Survival. L929 fibroblast cells were treated with $1.0 \mathrm{mM}$ $\mathrm{H}_{2} \mathrm{O}_{2}$ as a model study of oxidative stress and resulted in decrease of cell viability by $90 \%$ after $24 \mathrm{~h}$ of exposure. The antioxidant potential of the HEJFP was tested before and after $\mathrm{H}_{2} \mathrm{O}_{2}$ exposure for $3 \mathrm{~h}$ and concomitantly with $\mathrm{H}_{2} \mathrm{O}_{2}$ for $24 \mathrm{~h}$. The HEJFP was not effective in protecting cells against oxidative stress before or concomitantly with exposure to $\mathrm{H}_{2} \mathrm{O}_{2}$, resulting in low rate of cell survival. However, when cells were first treated with HEJFP for $24 \mathrm{~h}$, followed by $\mathrm{H}_{2} \mathrm{O}_{2}$ exposure for $3 \mathrm{~h}$, the tested concentrations of 25,50, and $100 \mu \mathrm{g} / \mathrm{mL}$ protected the cells against adverse effects caused by $\mathrm{H}_{2} \mathrm{O}_{2}$-induced oxidative stress and maintained the cell viability (Figure 2 ).

3.5. Scratch Assay. L929 murine fibroblasts cell line was tested through the scratch assay to determine the capacity of these cells to migrate under HEJFP stimulus (Figure 3). L929 cells have a fast migration rate; then the time to evaluate the cell migration was determined as $12 \mathrm{~h}$ upon exposure to HEJFP. At $24 \mathrm{~h}$, scratch is almost closed, making it difficult to analyze images.

Although concentrations of 0.5 and $100 \mu \mathrm{g} / \mathrm{mL}$ increased the cell migration rate after $12 \mathrm{~h}$, the effect was not significant when compared to control (Table 2).

\section{Discussion}

Plant extracts can be efficient in helping the wound healing process if they contain phytochemicals with antimicrobial and antioxidant activities and free radical scavengers and 
TABLE 1: Antioxidant activity of HEJFP determined by the DPPH assay.

\begin{tabular}{lc}
\hline Incubation time $(\mathrm{min})$ & \% inhibition of DPPH radical \\
\hline 5 & $83.6 \pm 1.83$ \\
10 & $88.09 \pm 1.52$ \\
20 & $90.18 \pm 1.02$ \\
30 & $91.01 \pm 0.42$ \\
40 & $91.36 \pm 1.01$ \\
50 & $91.88 \pm 1.28$
\end{tabular}

Values are mean $\pm \mathrm{SD}(n=3)$.

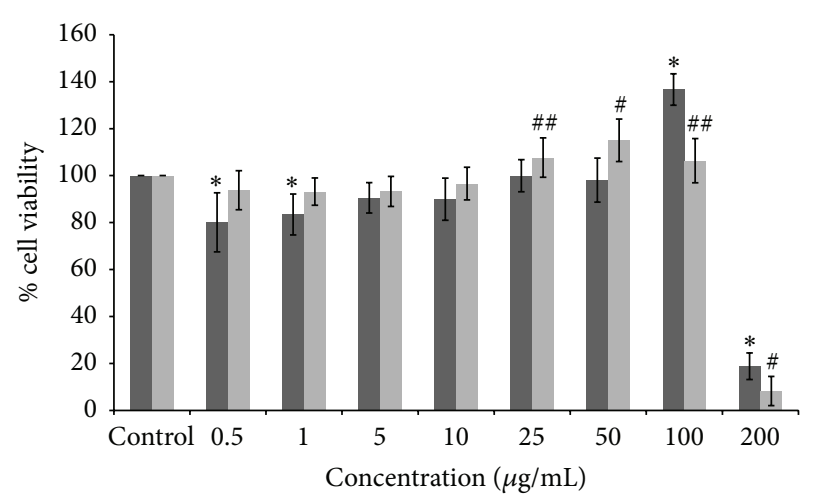

$24 \mathrm{~h}$

$48 \mathrm{~h}$

FIGURE 1: Percentage of survival of L929 fibroblast cells treated with HEJFP after $24 \mathrm{~h}$ and $48 \mathrm{~h}$. Data are expressed as a mean $\pm \mathrm{SD}(n=$ 18). * indicates $P<0.01$ against control for $24 \mathrm{~h}$; \# indicates $P<0.01$ and \#\# indicates $P<0.05$ against control for $48 \mathrm{~h}$.

TABLE 2: Scratch length $(\mu \mathrm{m})$ and cell migration rate (\%) of L929 murine fibroblasts treated with HEJFP determined by the scratch assay.

\begin{tabular}{lcc}
\hline & Length within the scratch $(\mu \mathrm{m})$ & \% migration rate \\
\hline Time 0 & $859.97 \pm 113.9$ & 0 \\
Control & $246.73 \pm 62.84$ & $71.31 \pm 7.3$ \\
$0.5 \mu \mathrm{g} / \mathrm{mL}$ & $157.56 \pm 53.58$ & $81.68 \pm 6.23$ \\
$5 \mu \mathrm{g} / \mathrm{mL}$ & $261.91 \pm 99.32$ & $69.54 \pm 11.55$ \\
$25 \mu \mathrm{g} / \mathrm{mL}$ & $263.36 \pm 73.4$ & $71.42 \pm 8.53$ \\
$50 \mu \mathrm{g} / \mathrm{mL}$ & $245.79 \pm 138.65$ & $69.37 \pm 16.12$ \\
$100 \mu \mathrm{g} / \mathrm{mL}$ & $183.31 \pm 91.15$ & $78.57 \pm 10.6$ \\
\hline
\end{tabular}

Values are mean $\pm \mathrm{SD}(n=8)$.

active compounds that enhance mitogenic activity, angiogenesis, collagen production, and DNA synthesis [20].

Jaboticaba fruit peel has a promising potential as a wound healing enhancer duo to its biomass rich in phenolic compounds. Indeed, those secondary metabolites have a wellknown antioxidant activity that prevents tissue damage and stimulates wound healing $[11,21]$.

The evaluation of the effectiveness of HEJFP in wound healing process was performed in vitro using L929 murine fibroblasts cell line. Nowadays, cell culture is a popular and effective method to test the sensitivity of cells to selected groups present in the microenvironment. Fibroblasts cell cultures have been proposed as a method for testing wound healing activity in vitro [22].

Hydrogen peroxide-induced oxidative stress is an alternative to evaluate extract's antioxidant activity in cells. $\mathrm{H}_{2} \mathrm{O}_{2}$ is an important molecule in wound healing process, the effect of which shall be under control of a molecular antioxidant apparatus such as SOD, GPx, and phospholipid hydroperoxide glutathione peroxidase [23]. A cytoprotective effect of HEJFP was detected when oxidative stress was induced to cells after the treatment with the extract. In this sense, a plausible assumption takes into account the fact that the protective effect of the extract could be related to the antioxidant activity thereof, corroborated by the results obtained through DPPH assay.

Xu et al. [11] also found a protective effect against hydrogen peroxide-induced oxidative stress in keratinocytes and fibroblasts of black soybean seed coat extract. The authors assigned this effect to the antioxidant activity of anthocyanins, metabolites that belong to phenolic group and are found in abundance in jaboticaba fruit peels.

Cell proliferation and migration are two extremely important features during the tissue formation phase in the wound healing. Scratch assay is a form to mimic a wound in vitro and evaluate the cell migration rate. Once the cell monolayer is disrupted, the loss of cell-cell interaction results in increasing concentration of growth factors and cytokines at the wound edge, initiating migration and proliferation of cells [24]. Interestingly, although the HEJFP was not able to increase cell migration rate, the extracts at 25,50 , and $100 \mu \mathrm{g} / \mathrm{mL}$ promoted fibroblasts proliferation. This mitogenic effect is a positive event for wound healing process because fibroblasts are important cells involved in wound contraction and ECM production [18].

\section{Conclusion}

HEJFP has been shown to be in vitro a potential plant extract, enhancing the wound healing process. The cytoprotective effect of HEJFP in fibroblasts against hydrogen peroxideinduced oxidative stress can be assigned to its phenolic compounds, which have been proven to be strong antioxidants. Besides, HEJFP induced mitogenic activity of fibroblasts, an important feature in the wound healing process. Further investigations are necessary to isolate and identify the compounds responsible for these activities, as previous findings refer to the ellagic acid as a major compound in the HEJFP (unpublished data). Besides, in vitro studies measuring antioxidant enzymes will help understand the mechanisms underlying the effects described herein for the wound healing process.

\section{Competing Interests}

The authors declare that there are no competing interests regarding the publication of this paper. 


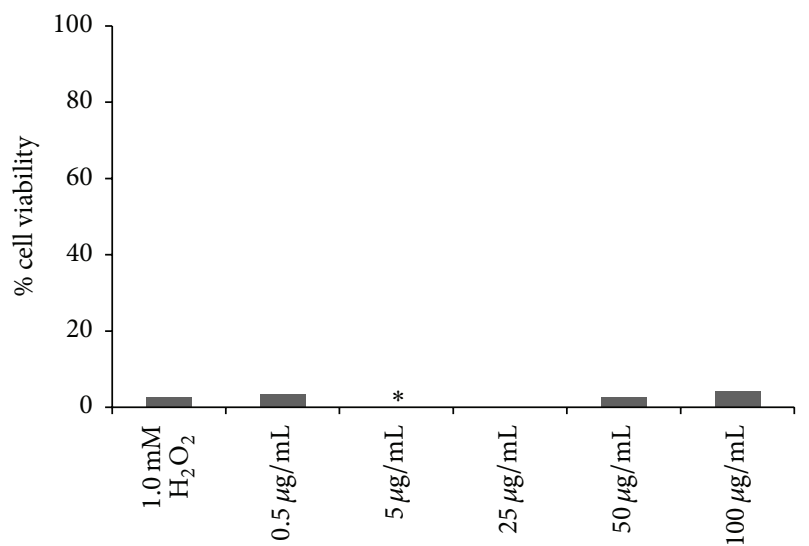

(a)

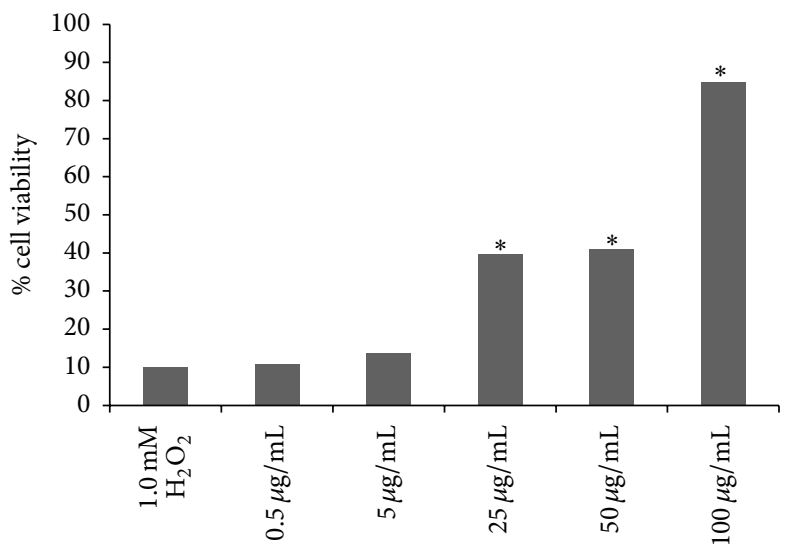

(b)

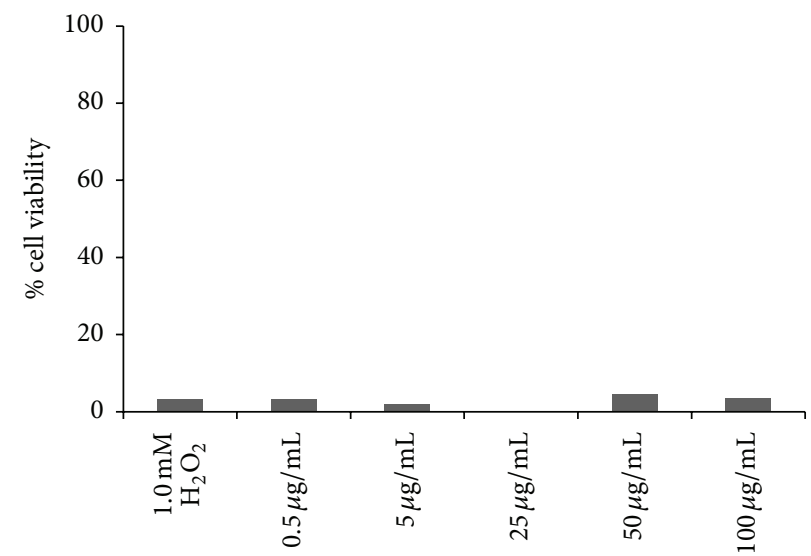

(c)

Figure 2: Viability (\%) of cells treated with HEJFP after $\mathrm{H}_{2} \mathrm{O}_{2}$ exposure (a) and before $\mathrm{H}_{2} \mathrm{O}_{2}$ exposure (b) and concomitantly with $\mathrm{H}_{2} \mathrm{O}_{2}$ (c). Data are expressed as a median $(n=16)$. * indicates $P<0.01$ against $1.0 \mathrm{mM} \mathrm{H}_{2} \mathrm{O}_{2}$ control.

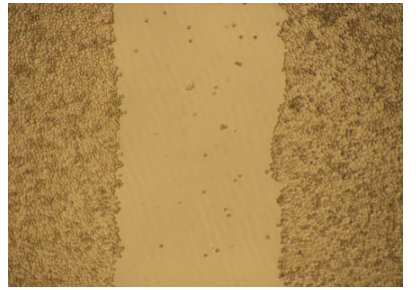

(a)

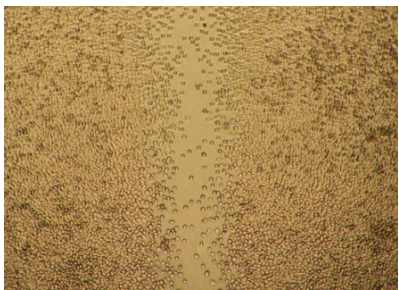

(b)

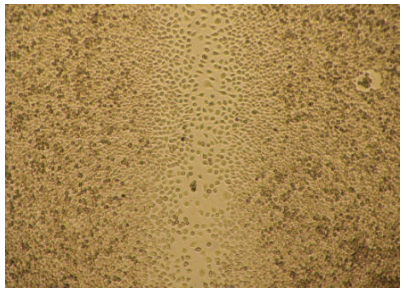

(c)

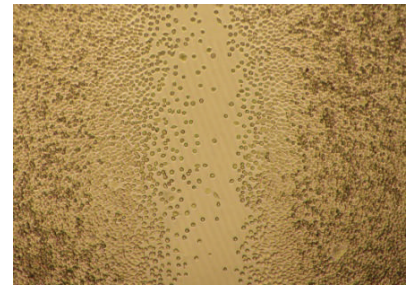

(d)

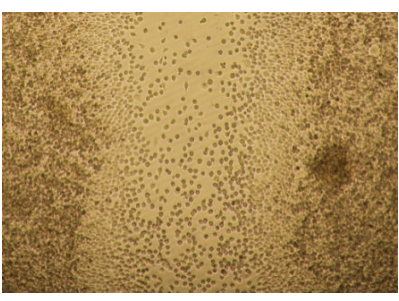

(e)

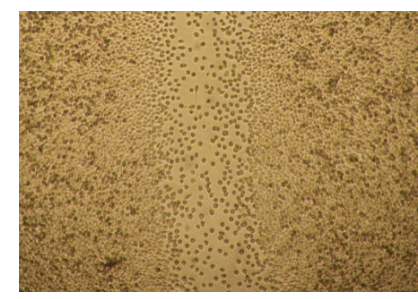

(f)

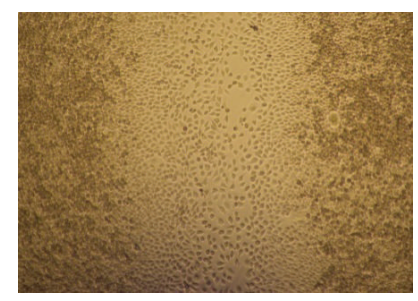

(g)

FIGURE 3: Microscopy images of L929 fibroblast cells migration after scratch ((a)-time 0) and after 12 h of HEJFP treatment. (b) Control, (c) $0.5 \mu \mathrm{g} / \mathrm{mL}$, (d) $5 \mu \mathrm{g} / \mathrm{mL}$, (e) $25 \mu \mathrm{g} / \mathrm{mL}$, (f) $50 \mu \mathrm{g} / \mathrm{mL}$, and (g) $100 \mu \mathrm{g} / \mathrm{mL}$. 


\section{References}

[1] A. J. Singer and R. A. F. Clark, "Cutaneous wound healing," New England Journal of Medicine, vol. 341, no. 10, pp. 738-746, 1999.

[2] R. A. F. Clark, "Wound repair: overview and general considerations," in The Molecular and Cellular Biology of Wound Repair, pp. 3-50, Plenum Press, New York, NY, USA, 1996.

[3] D. Neagos, V. Mitran, G. Chiracu et al., "Skin wound healing in a free floating fibroblast populated collagen lattice model," Romanian Journal of Biophysics, vol. 16, no. 3, pp. 157-168, 2006.

[4] C. Dunnill, T. Patton, J. Brennan et al., "Reactive oxygen species (ROS) and wound healing: the functional role of ROS and emerging ROS-modulating technologies for augmentation of the healing process," International Wound Journal, vol. 12, no. 6, pp. 1-8, 2015.

[5] P. Martin, "Wound healing-aiming for perfect skin regeneration," Science, vol. 276, no. 5309, pp. 75-81, 1997.

[6] G. C. Gurtner, S. Werner, Y. Barrandon, and M. T. Longaker, "Wound repair and regeneration," Nature, vol. 453, no. 7193, pp. 314-321, 2008.

[7] B. Hinz and G. Gabbiani, "Cell-matrix and cell-cell contacts of myofibroblasts: role in connective tissue remodeling," Thrombosis and Haemostasis, vol. 90, no. 6, pp. 993-1002, 2003.

[8] A. Desmoulière, M. Redard, I. Darby, and G. Gabbiani, "Apoptosis mediates the decrease in cellularity during the transition between granulation tissue and scar," The American Journal of Pathology, vol. 146, no. 1, pp. 56-66, 1995.

[9] M. Gangwar, M. K. Gautam, S. Ghildiyal, G. Nath, and R. K. Goel, "Mallotus philippinensis Muell. Arg fruit glandular hairs extract promotes wound healing on different wound model in rats," BMC Complementary and Alternative Medicine, vol. 15, article 123, 2015.

[10] R. Moseley, J. E. Stewart, P. Stephens, R. J. Waddington, and D. W. Thomas, "Extracellular matrix metabolites as potential biomarkers of disease activity in wound fluid: lessons learned from other inflammatory diseases?" British Journal of Dermatology, vol. 150, no. 3, pp. 401-413, 2004.

[11] L. Xu, T. H. Choi, S. Kim et al., "Anthocyanins from black soybean seed coat enhance wound healing," Annals of Plastic Surgery, vol. 71, no. 4, pp. 415-420, 2013.

[12] J. Morton, Fruits of Warm Climates, Julia Morton, Miami, Fla, USA, 1987.

[13] H. Lorenzi, Árvores Brasileiras: Manual de Identificação e Cultivo de Plantas Arbóreas Nativas do Brasil, Instituto Plantarum, Nova Odessa, Brazil, 2000.

[14] A. M. V. Cruz and M. A. C. Kaplan, "Uso medicinal de espécies das famílias Myrtaceae e Melastomataceae no Brasil," Floresta Ambiente, vol. 11, no. 1, pp. 47-52, 2004.

[15] R. Randhir, P. Shetty, and K. Shetty, "L-DOPA and total phenolic stimulation in dark germinated fava bean in response to peptide and phytochemical elicitors," Process Biochemistry, vol. 37, no. 11, pp. 1247-1256, 2002.

[16] R. D. Petry, G. G. González Ortega, and W. B. Silva, "Flavonoid content assay: influence of the reagent concentration and reaction time on the spectrophotometric behavior of the aluminium chloride-flavonoid complex," Pharmazie, vol. 56, no. 6, pp. 465-470, 2001.

[17] Y. K. Kim, Q. Guo, and L. Packer, "Free radical scavenging activity of red ginseng aqueous extracts," Toxicology, vol. 172, no. 2, pp. 149-156, 2002.
[18] N. Balekar, N. G. Katkam, T. Nakpheng, K. Jehtae, and T. Srichana, "Evaluation of the wound healing potential of Wedelia trilobata (L.) leaves," Journal of Ethnopharmacology, vol. 141, no. 3, pp. 817-824, 2012.

[19] Y. Ponnusamy, N. J.-Y. Chear, S. Ramanathan, and C.-S. Lai, "Polyphenols rich fraction of Dicranopteris linearis promotes fibroblast cell migration and proliferation in vitro," Journal of Ethnopharmacology, vol. 168, pp. 305-314, 2015.

[20] P. K. Ghosh and A. Gaba, "Phyto-extracts in wound healing," Journal of Pharmacy and Pharmaceutical Sciences, vol. 16, no. 5, pp. 760-820, 2013.

[21] A. Scalbert, C. Manach, C. Morand, C. Rémésy, and L. Jiménez, "Dietary polyphenols and the prevention of diseases," Critical Reviews in Food Science and Nutrition, vol. 45, no. 4, pp. 287306, 2005.

[22] Y. Abe, K. Inagaki, A. Fujiwara, and K. Kuriyama, "Wound healing acceleration of a novel transforming growth factor- $\beta$ inducer, SEK-1005," European Journal of Pharmacology, vol. 408, no. 2, pp. 213-218, 2000.

[23] H. Steiling, B. Munz, S. Werner, and M. Brauchle, "Different types of ROS-scavenging enzymes are expressed during cutaneous wound repair," Experimental Cell Research, vol. 247, no. 2, pp. 484-494, 1999.

[24] C.-C. Liang, A. Y. Park, and J.-L. Guan, "In vitro scratch assay: a convenient and inexpensive method for analysis of cell migration in vitro," Nature Protocols, vol. 2, no. 2, pp. 329-333, 2007. 


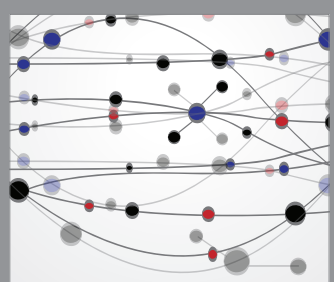

The Scientific World Journal
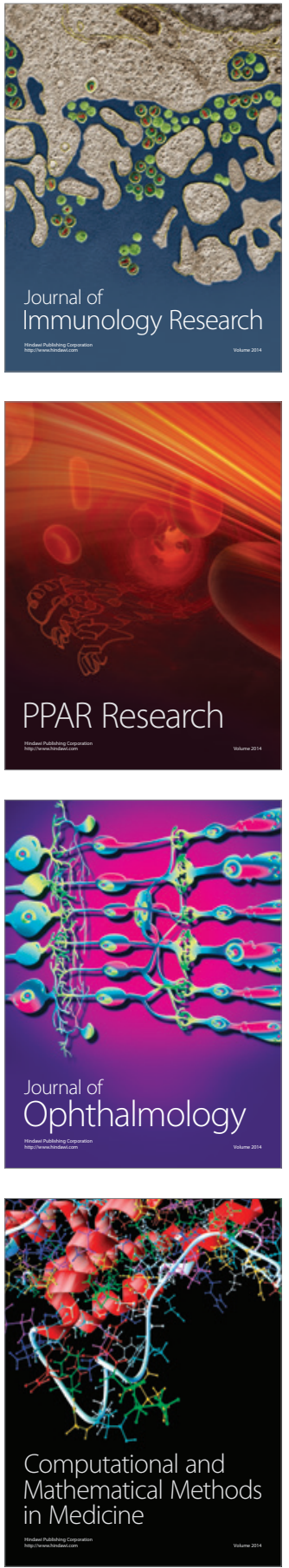

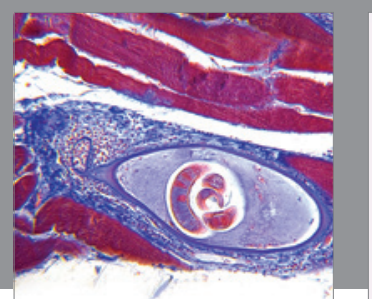

Gastroenterology Research and Practice

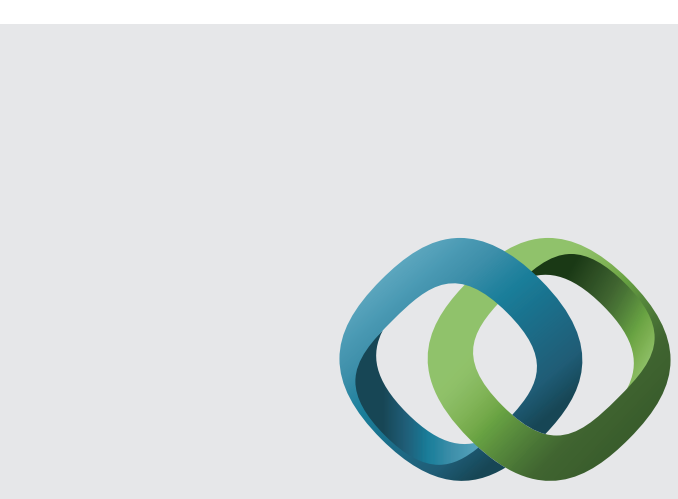

\section{Hindawi}

Submit your manuscripts at

http://www.hindawi.com
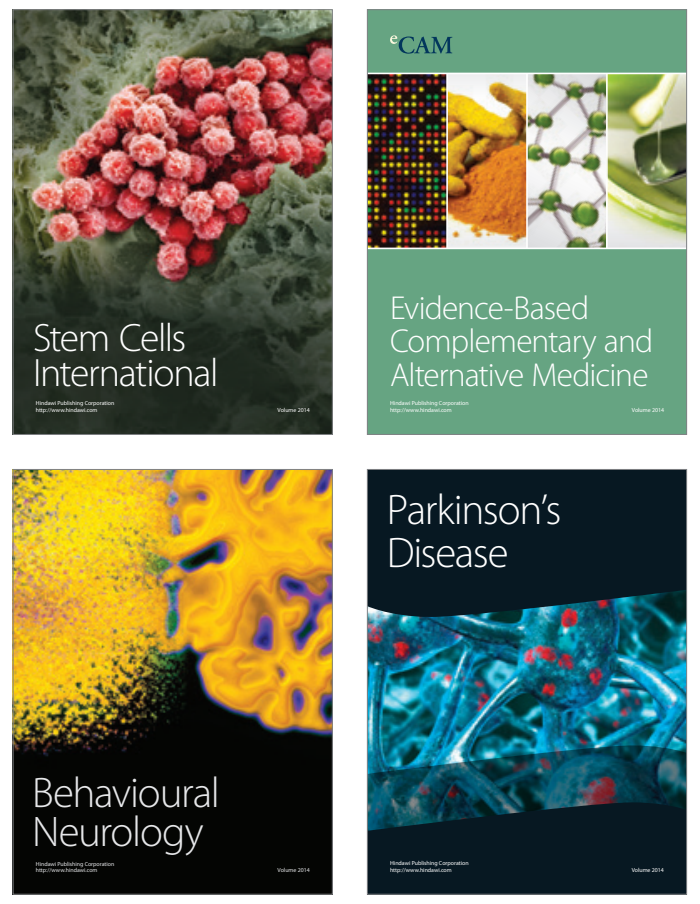
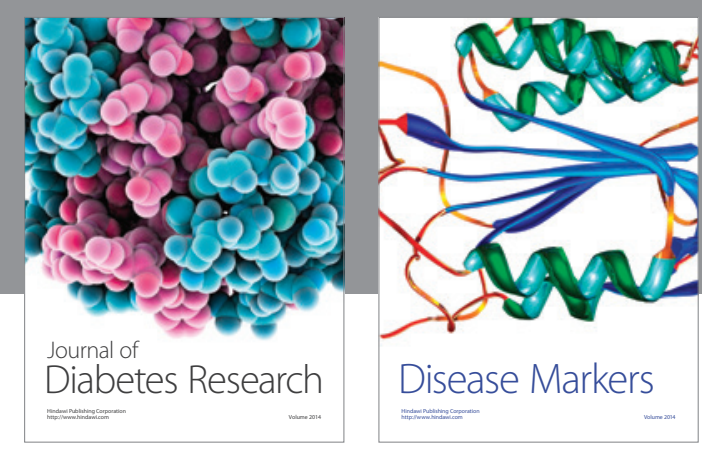

Disease Markers
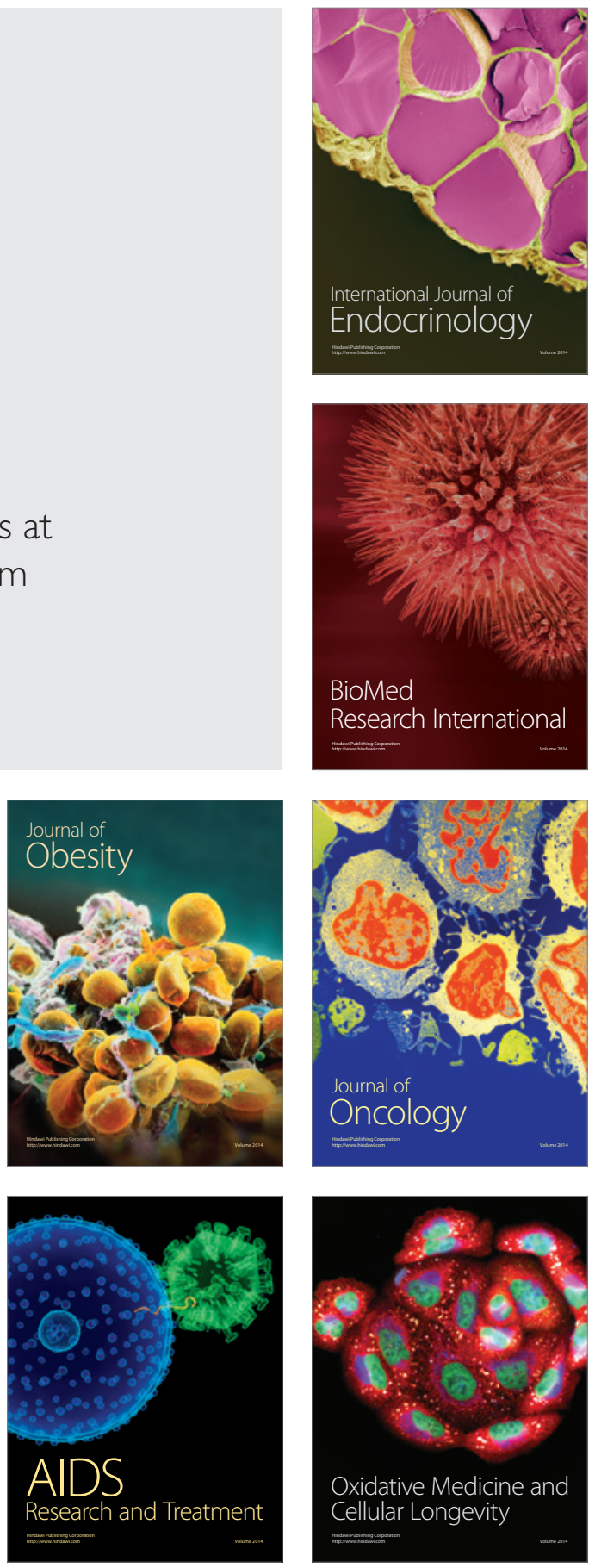